\title{
Brown V. The Board: The Next 50 Years Of Achievement? Empirical Analysis And Projection
}

Michael O. Adams, (Email: adams_mo@tsu.edu), Texas Southern University

Carroll G. Robinson, (E-mail: robinson_cg@tsu.edu), Texas Southern University

Gbolahan S. Osho, (Email: oshogs@tsu.edu),Texas Southern University

Oluwatoyin K. Adejonwo, (E-mail: toyinadejonwo@ hotmail.com ), Lewis and Clark Law School

\begin{abstract}
It's been over 50 years since the United States Supreme Court ruled in favor of dismantling the legal basis for racial segregation in our school systems. Many agree that Brown itself was the catalyst for a plethora of decisions which were made to increase the equality of blacks in America, especially in education. But the question still remains what have blacks gained from this ruling? Have they improved their levels of scholastic achievement since 1954? Where are they in comparison to their white counterparts? Researchers have discussed sociological effects of the case, but what quantitatively do the results show? This paper will review empirical comparisons between levels of achievement of blacks and whites, yesterday and today, and make suggestions on how blacks and whites might compare in the next 50 years.
\end{abstract}

\section{INTRODUCTION}

thas been over fifty years since the Thurgood Marshall led litigation team won the US Supreme Court's
Brown vs. the Board of Education ruling. This case was able to break the binds of segregation, but it was
not strong enough to break the binds of racism. As a result, many people are still dissatisfied with current
levels of achievement by African American students on all levels of education, but especially in secondary and higher
education. Many theorize that the result of the differences in the level of achievement between blacks and whites stem
from sociological differences between blacks and whites, stating that the different educational outcomes in black and
white achievement were based on biological differences, family and cultural influences, and the effects of social
stratification, school characteristics, and organizational processes (Hallinan 2001). More realistic effects would
include racism, the lack of governmental enforcement on laws, and the levels of funding in the segregated schools.

\section{THE BEGINNING, NOT THE END}

In 1954, in the Brown vs. Board the US Supreme Court found that state laws requiring race-based segregation in public elementary and secondary schools violated the Equal Protection clause of the Fourteenth Amendment. It was the expectation and was highly celebrated that Brown would dramatically increase the levels of achievement for blacks students, resulting in an increase in Blacks getting better jobs, and better opportunities for their families. It didn't happen that way, because in spite of the Supreme Court decision, there was resistance (Mackenzie,1993)., but the surprise is that a decade after Brown virtually nothing had changed for African American students living in the eleven states of the former Confederacy that requires race-based segregation by law. For example, in the 1963-1964 school year, barely one in one hundred (1.2\%) of these African American students was in a nonsegregated school. That means that for nearly ninety-nine of everyone hundred African American children in the Southern a decade after Brown, the finding of a constitutional right changed nothing. A unanimous landmark Supreme Court decision had no effect on their lives. This raises the question why was there no change. The answer in a nutshell is that there was no political pressure to implement the decision and a great deal of pressure to resist it. On the 
executive level, there was little support for desegregation until the Johnson presidency and despite the Cooper v Aaron and the sending of troops to Little Rock in 1957, as of June 1963 only sixty nine out of 7700 students at the supposedly desegregated formerly white junior and senior high schools of Little Rock were black (Rosenberg, 1999).

\section{WHAT CHANGED?}

One of the things that Brown was able to do was to overturn nearly sixty years of court-sanctioned racial segregation. There have been a number of decisions after Brown clarifying exactly what the decision meant. On September 12, 1958 in Cooper vs. Aaron, the U.S. Supreme Court rules unanimously in a six-paragraph decision that integration must proceed immediately at Central High. In 1968, there was Green v. County School Board of New Kent County, Virginia, in which the Court declared that racial desegregation extended to every facet of school operations. The faculties needed to be desegregated, along with staff, transportation facilities and even extra-curricular activities. Because in spite of the Brown decisions, some adults didn't want certain students in clubs and didn't want them in certain classes (Mackenzie 1993).

Then the courts moved again, because there was still resistance to equal education, opportunity and access. In 1971, Swann v. Charlotte-Mecklenburg Board of Education addressed the problems which arise when the minorities in metropolitan areas become the majority. Then we moved to U.S. v. Jefferson County Board of Education, where the courts decided there were lasting effects of inequalities and there was need for compensatory programming. In 1977, a very important decision, Milliken v. Bradley, was a case in Detroit which held that reassignment and compensatory and remedial actions were to be taken. Last, a more recent decision, still trying to remove vestiges of desegregation, was Jenkins v. Missouri, a Kansas City decision which held that the state would have to spend millions of dollars to try to equalize the education of students in urban districts (Mackenzie, 1993).

Other related District Court decisions were Briggs v. Elliott in South Carolina, which some consider to be even more important than the Brown case. Briggs was the first case to reach the Supreme Court. The Supreme Court combined the case with Brown, and placed Brown before Briggs, so that the formal name of the case became Brown v. Board of Education of Topeka, Kansas. According to Justice Tom Clark, the Court decided to use the name of another case outside the South so that the nation would not see the case as just a Southern case (Woods, "Modjeska Simkins and the NAACP," 111). The Court also combined Brown and Briggs with a desegregation case from Virginia, and then it added two other cases, one from Delaware and one from the District of Columbia. These cases were Davis v. County School Board in Virginia, and in Delaware Gebhart v. Belton. In Briggs v. Elliott and the Davis v. County School Board, the Courts ordered that the schools be equalized, having established that the facilities and curriculum were unequal. In Delaware, however, after recognizing that the Black schools were inferior with respect to teacher training, pupil-teacher ratio, extra- curricular activities, physical plant, and time and distance of travel, the Court ordered immediate admission of Black plaintiffs into previously all White schools (Rosenberg, 1999).

A group of Southern politicians declared their feelings about the Brown v. Board of Education decision in the Southern Manifesto, the second reading for this week. Essentially they declared that it represents a clear abuse of judicial power. They felt that the federal judiciary was encroaching on the rights of the people. Education has not been mentioned in the Constitution or in the 14th Amendment or any other amendment. They felt that this action would destroy the amicable relationship between the White and Black races that had been created over the last century. Forcing the races to change their relationship could only produce misunderstanding and hostility (Wilkins, 1993).

\section{HOW DID BLACKS ACHIEVE IN COMPARISON TO WHITES AFTER BROWN?}

By the 1972 -1973 school year, more than 91 percent of African American children in the eleven states of the former confederacy were in a nonsegregated school. Eighteen years after Brown, southern school systems were desegregated. Change came to the southern school systems in the wake of congressional and executive branch action. Title VI of the 1964 Civil rights act permitted the cut-off of federal funds to programs, and the 1965 elementary and secondary education act provided a great deal of federal money to generally poor southern school districts. 
By the 1971-1972 school year for example federal funds comprised from between 12 percent and 27.8 percent of southern state school budgets, up from between 4.6 percent and 11.1 percent in the 1963-1964 school year. This combination of federal funding and Title VI gave the executive branch a tool to induce desegregation when it chose to do so. When the US Department of Health, Education, and Welfare began to threaten fund cut-offs to school districts that refused to desegregate, dramatic change occurred. By the 1972-1973 school year, more than 91 percent African American school children in the eleven southern states were in integrated schools, up from 1.2 percent in the 1963-1964 school year. With only the constitutional right in force in the 1963-1964 school year, no more that 5.5 percent of African American children in any southern state were in school with whites. By the 1972-1973 school year, when economic incentives were offered for desegregation, and costs imposed for failure to desegregate, in no southern state were fewer that 8 0percen of African American children in integrated schools. School desegregation occurred in the years 1968-72, then, because a set of conditions provided incentives for it, and imposed costs for failing to desegregate. When those conditions were lacking, as in the first decade after brown, constitutional rights were flouted. What a court decision was unable to accomplish, federal dollars were able to achieve (Rosenburg 1999).

Researchers found that the in 1982 and 1992 white high school seniors were as much as 10 times more likely to score in the top five percent of the national distribution on academic skills test (Hedges and Nowell, 1998). After analyzing the data from six national surveys, they reported that while the gap had narrowed since 1970, the average American black student still scored below 75 percent of American white students on most standardized tests (Hallman, 2001). The National Assessment of Educational Progress (NAEP) was a survey begun in the 1970s to assess trends in students' progress, also provides evidence of a black-white achievement gap. The results were based on tests administered to students in reading, mathematics, science and writing. These test scores show a significant lag in the achievement of black students. Results showed that in 1996 black high school seniors were reading at a rate similar to $8^{\text {th }}$ grade children.

Figure1. NAEP Test Scores in Reading for $12^{\text {th }}$ Grade Black and White Students: 1971-1996

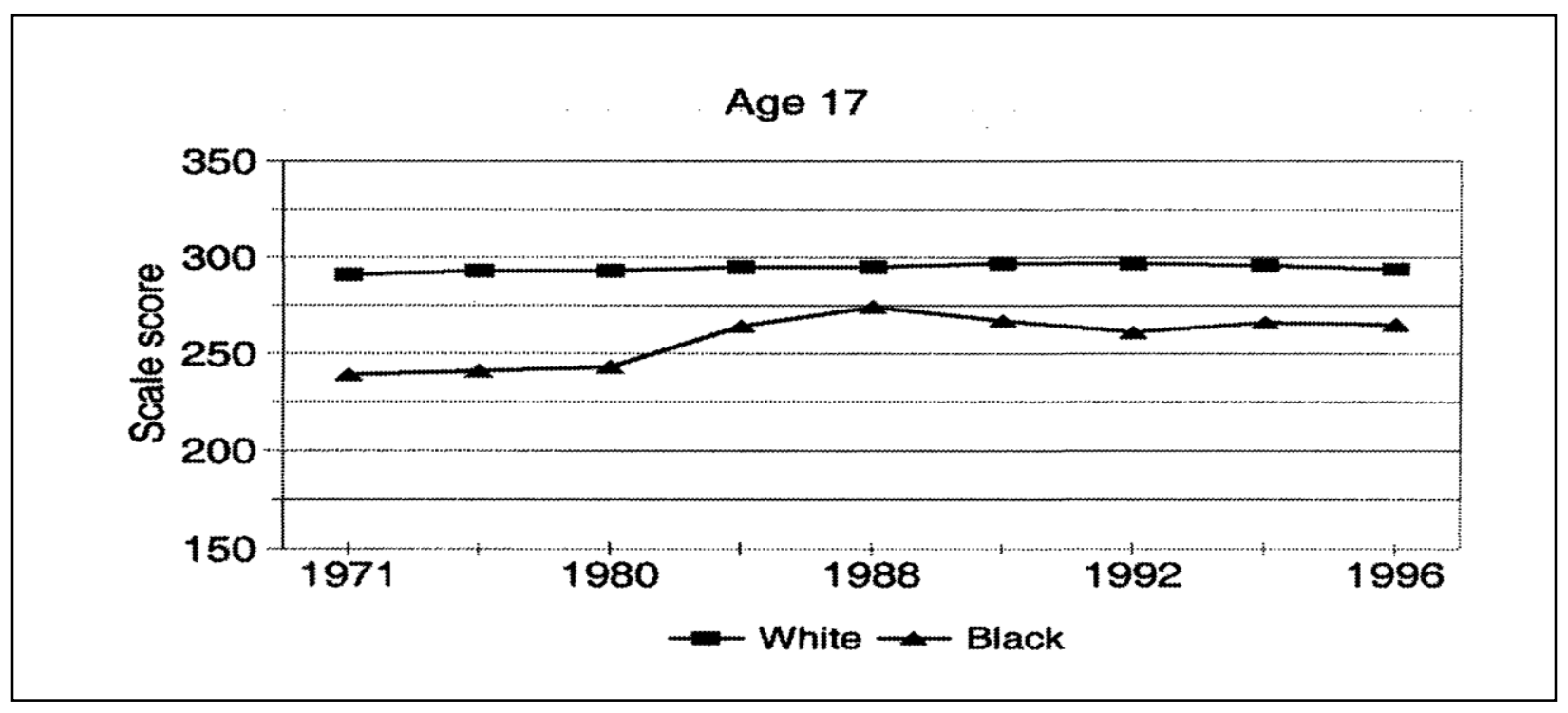

\section{CONCLUSION}

First, while African-American educational attainment has improved, the amount of education needed to have a real chance in life has grown even more. Second, general trends do not reflect how really awful educational conditions are in some schools, in some regions, and for some groups, including African-Americans in urban areas. And third, the gap between white and African-American achievement remains substantial (Wilkins, 1993). 
The minority population of these United States is growing, and in many geographic areas, the term minority has lost its statistical meaning. Around the year 2020, one-third of our nation will be minority, including Asian-Americans. By the last quarter of the 21 st century, as a result of immigration and differing birth rates, minorities may have become the majority. This nation is not preparing to meet this change. In our schools, the future is already upon us. In our country, between 1968 and 1986, the number of white school children fell by 16\%, the number of black children increased by $5 \%$, and the number of Hispanic children increased by $100 \%$. While there has been some success in school desegregation over the last 25 years, in general segregation has not decreased significantly since 1970. In fact, in some areas it has gotten worse. Today, 22 or 23 of the 25 largest central-city school districts in this nation are predominantly minority (Wilkins, 1993).

Perhaps desegregation is not the key. Possibly there are other, more important factors on which we should focus if we are ever to provide a quality education for all our children. Maybe the push to raise test scores, to institute competency tests, and to increase teacher standards without addressing root causes of the problems has hurt more than it has helped. African-Americans have long understood that education, above all, is the way to freedom and opportunity. For centuries, we have fought for an educational system that responds to the needs of our children. Without some very definite change in the way we view our interdependence on each other, perhaps the need for this discussion will be with us in the year 2033, 40 years from now (Wilkins, 1993). Rudman and Featherstone (1968) of Michigan State University cited a colleague as projecting in Urban Schooling that "by 1999 our urban population will be much higher, even in today's purchasing power." We need to see a new discussion in state legislatures concerning rich school districts versus poor districts.

\section{Reference}

1. Hallinan, M. T. (2001). Sociological Perspectives on Black-White Inequalities in American Schooling. Sociology of Education, pp.50-70 2001.

2. Hallman, P. (2001). The college of education. [On-line]. Available: http://www.education. $\underline{\text { sfasu.edu/CoEFacts/deanintro.html }}$

3. Hedges, L. V., \& Nowell, A. (1998). Black-white test score convergence since 1965. In C. Jencks \& M. Phillips (Eds.), The black-white test score gap (pp. 149-181). Washington, DC: Brookings Institution Press.

4. Mackenzie, L. On Our Feet. A Handbook on Gender and Popular Education Workshops. Bellville, South Africa: Centre for Continuing Education, University of the Western Cape, 1993. (ED 379 400)

5. Rudman, H. and Featherstone, R. (1968), Urban Schooling, Harper \& Row: New York (Citing R. Moley in An Essay For News Week on What Kind of A City and Citing J.M. Klotsche in The Urban University).

6. Rosenberg, Gerald N., African-American Rights After Brown, 1999, 24(2) 2004

7. Wilkins, Roger, Dream Deferred But not Defeated in E.C. Lagemann and L. P Miller, eds. Brown v. the Board of Education: The Challenger for Today's Schools 14-18(New York: Teachers College Press, Columbia University 1996) 